Zahro, et al/Jurnal Ekonomi Syariah Teori dan Terapan Vol. 6 No. 6 Juni 2019: 1209-1227; ANALISIS THEORY OF PLANNED BEHAVIOUR DAN PENGETAHUAN TERHADAP NIAT BERINFAQ JAMAAH MAJELIS TAKLIM KECAMATAN SUKOMANUNGGAL SURABAYA

\title{
ANALISIS THEORY OF PLANNED BEHAVIOUR DAN PENGETAHUAN TERHADAP NIAT BERINFAQ JAMAAH MAJELIS TAKLIM KECAMATAN SUKOMANUNGGAL SURABAYA'
}

\author{
Robbi Rodliyya Zahro \\ Departemen Ekonomi Islam-Fakultas Ekonomi dan Bisnis-Universitas Airlangga \\ Email: rrzahro@gmail.com \\ Sunan Fanani \\ Departemen Ekonomi Islam-Fakultas Ekonomi dan Bisnis-Universitas Airlangga \\ Email: sunan-f@feb.unair.ac.id
}

\begin{abstract}
:
This study aims to determine the effect of the Theory of Planned Behavior and knowledge of the intention to invest in the assembly of the Taklim Muhammadiyah SubDistrict of Sukomanunggal Surabaya. Primary data retrieval in this study used a questionnaire with a sample of 40 taklim assemblies in Sukomanunggal sub-district, Surabaya. The characteristics of the sample in this study were the pilgrims who attended the recitation in the assembly of taklim Muhammadiyah, Sukomanunggal, Surabaya. The sampling technique is Non-Probability Sampling and Simple Random Sampling. This study uses a quantitative approach with multiple linear regression analysis. The endogenous variable in this study is the intention to invest, while the exogenous variable used is part of the Theory of Planned Behavior which consists of attitudes, subjective norms, and Perceived Behavior Control and Knowledge. The results of this study indicate that simultaneously and partially attitudes, subjective norms, Perceived Behavior Control, and knowledge have a significant effect on the intention to invest in the assembly of taklim members of Muhammadiyah, Sukomanunggal District, Surabaya. Suggestions for further research to add to the scope of research subjects so that more general information can be obtained about related research, and using other variables outside of this research variable because it should be suspected that there are still several other factors that can influence intention to invest.
\end{abstract}

Keywords: Theory Of Planned Behaviour, Knowledge, Infaq, Intention.

\section{PENDAHULUAN}

\section{Latar Belakang}

Perubahan dan pergeseran tata nilai kehidupan di masyarakat membuat manusia hanya berfikir untuk mengejar kehidupan dunia sampai tidak menghiraukan halal dan haram, sehingga melupakan hubungannya dengan Allah dan juga hubungannya dengan manusia. Hal ini dapat mempengaruhi perilaku manusia ke arah yang tidak baik.

Keseimbangan antara dunia dan akhirat telah diajarkan dalam agama Islam, berarti bahwa dunia dan akhirat $\begin{array}{lrr}\text { keduanya } & \text { haruslah } & \text { sama-sama } \\ \text { diperjuangkan. } & \text { Untuk } & \text { mencapai }\end{array}$ keseimbangan tersebut, seseorang tidak hanya memperhatikan sifat lahiriyah tetapi juga kebutuhan rohani (spiritual). Hal ini sesuai dengan Surat Al-Qashash ayat 77 yang artinya, "Dan carilah pada apa yang telah dianugerahkan Allah kepadamu (kebahagiaan) negeri akhirat, dan janganlah kamu melupakan bahagianmu dari (kenikmatan) duniawi dan berbuat baiklah (kepada orang lain) sebagaimana Allah telah berbuat baik, kepadamu, dan janganlah kamu berbuat

\footnotetext{
${ }^{1}$ Jurnal ini merupakan bagian dari skripsi Robbi Rodliyya Zahro, NIM: 041311433061, yang diuji pada tanggal 21 Januari 2019.
} 
Zahro, et al/Jurnal Ekonomi Syariah Teori dan Terapan Vol. 6 No. 6 Juni 2019: 1209-1227; ANALISIS THEORY OF PLANNED BEHAVIOUR DAN PENGETAHUAN TERHADAP NIAT BERINFAQ JAMAAH MAJELIS TAKLIM KECAMATAN SUKOMANUNGGAL SURABAYA

kerusakan di (muka) bumi. Sesungguhnya Allah tidak menyukai orang-orang yang berbuat kerusakan" (QS. Al-Qashash:77).

Ada beberapa cara yang dilakukan umat Islam dalam memenuhi kebutuhan rohaninya, salah satunya adalah dengan mengikuti pengajian. Pengajian atau taklim merupakan suatu bentuk kegiatan keagamaan dalam Islam, dimana seseorang memberikan pengetahuan tentang agama kepada orang lain dalam rangka memberikan kehidupan beragama yang baik serta dapat memupuk semangat ukhuwah islamiyah atau persaudaraan Islam, sehingga dapat memberikan nilai-nilai keagamaan atau nilai-nilai kerohanian yang luhur bagi pribadi seseorang. Pada umumnya pengajian atau majelis taklim adalah lembaga pendidikan non formal yang memiliki kurikulum tersendiri yang dilaksanakan berkala dan teratur dan diikuti oleh jamaah yang relatif banyak dan bertujuan untuk membina dan mengembangkan hubungan yang santun dan serasi antara manusia dan Allah SWT, antara manusia dengan sesamanya, dan antara manusia dengan lingkungannya. Pengajian tidak hanya diikuti oleh orangorang tertentu, seperti siswa dan santri, melainkan juga diikuti oleh bapak-bapak, ibu-ibu, remaja dan anak-anak serta untuk semua kalangan.

Islam mengajarkan bahwa setiap muslim mempunyai kewajiban untuk berusaha melaksanakan semaksimal mungkin semua syariah (aturan) Islam dalam segala aspek kehidupan, termasuk aspek ekonomi yang merupakan bagian ilmu sosial. Hubungan Islam komprehensif dengan ekonomi Islam, yaitu bahwa kajian ekonomi Islam mencakup aspek muamalah, muasyarah, akhlak dan sebagai landasannya adalah akidah dan ubudiah. Misalnya, pembahasan distribusi terhadap aspek ibadah yaitu zakat, infaq, serta sedekah. (Lukman Hakim, 2012:3)

Setiap manusia pasti mengehendaki agar hidupnya bahagia, sehingga menjadikan kebahagiaan sebagai tujuan hidupnya. Bagi seorang mukmin, kebahagiaan yang dicari adalah kebahagiaan yang hakiki, yaitu kebahagiaan dunia dan akhirat. Hal tersebut hanya bisa didapat melalui beragam ketaatan yang salah satunya adalah menunaikan kewajiban zakat dan infaq. Dengan menunaikan zakat dan infak dapat menjadi bukti iman kita kepada Allah dan sesama muslim yang membutuhkannya. Semakin tinggi nilai ketaatan manusia maka semakin tinggi pula kebahagiaan yang dirasakannya.

Menurut penelitian dari BAZNAS dan IPB, pada tahun 2015 Indonesia mempunyai potensi zakat sebesar Rp 280 Triliun. Hal ini menunjukkan bahwa potensi zakat di Indonesia sangatlah besar. Tetapi pada kenyataannya berdasarkan data dari BPS, dana zakat, infaq, dan sedekah nasional pada tahun 2015 yang mampu terhimpun di Indonesia hanya 1,4 persen yaitu sekitar $\operatorname{Rp} 4$ Triliun dari total potensi zakat (www.pusat.baznas.go.id). Hal ini 
Zahro, et al/Jurnal Ekonomi Syariah Teori dan Terapan Vol. 6 No. 6 Juni 2019: 1209-1227; ANALISIS THEORY OF PLANNED BEHAVIOUR DAN PENGETAHUAN TERHADAP NIAT BERINFAQ JAMAAH MAJELIS TAKLIM KECAMATAN SUKOMANUNGGAL SURABAYA

disebabkan karena keadaan ekonomi dan kurangnya kesadaran akan berzakat.Jika dilihat dari perhitungan potensi zakat yang sifatnya wajib saja mempunyai potensi yang besar, maka dapat diketahui bahwa potensi infaq juga besar, akan tetapi dana yang terhimpun masih belum maksimal. Hal ini disebabkan karena keinginan (niat) muslim untuk berinfaq masih kurang. Dan terdapat beberapa faktor yang mempengaruhi niat seseorang untuk berinfaq.

Menurut Ajzen (2005) terdapat tiga indikator utama yang dapat mempengaruhi niat seseorang untuk melaksanakan suatu perilaku, yaitu sikap terhadap suatu perilaku (attitude toward the behavior), norma subyektif tentang suatu perilaku (subjective norm), dan kontrol perilaku persepsian (perceived behavioralcontrol).Setiap individu memiliki kontrol pada dirinya yang dapat mendorongnya untuk melakukan suatu perilaku. Minat seseorang untuk melakukan perilaku tertentu ditentukan keyakinan atas pengetahuan yang diperoleh apakah perilaku tersebut akan berakibat positif atau negatif. Norma subjektif terbentuk dari motivasi untuk berperilaku sesuai harapan normatif. Kontrol perilaku berisikan aspek pengetahuan tentang kemudahan dan kesulitan untuk melakukan perilaku tertentu.

Selain norma subjektif, Rusti Rahayu dalam penelitiannya yang berjudul "Faktor-faktor Determinan
Motivasi Muzakki Membayar Zakat ke Lembaga Zakat", diperoleh hasil bahwa variabel pengetahuan, keyakinan, keluarga, momen bulan ramadhan, akuntabilitas, aksesibilitas, dan popularitas mempengaruhi motivasi muzakki untuk membayar zakat ke lembaga zakat. Dengan demikian dapat diketahui bahwa pengetahuan juga merupakan salah satu faktor yang mempengaruhi niat seseorang dalam berperilaku.

IImu atau pengetahuan dalam Islam dijelaskan pada Al-Qur'an surat AlIsra ayat 36 yang berbunyi:

Artinya: "Dan janganlah engkau turut apa-apa yang engkau tidak ada ilmu padanya, sesungguhnya pendengaran, penglihatan dan hati, semuanya akan ditanya."

Ayat Al-Qur'an diatas menjelaskan bahwa ilmu atau pengetahuan merupakan dasar dari segala tindakan manusia, karena tanpa ilmu segala tindakan manusia menjadi tidak terarah, tidak benar, dan tidak bertujuan. Dengan pengetahuan inilah manusia melakukan perbuatan amalnya. Jika manusia memiliki ilmu tetapi tidak beramal, maka ilmu tersebut akan sia-sia.

\section{Majelis Taklim Muhammadiyah} Kecamatan Sukomanunggal mempunyai program kerja aktif antara lain, program kerja di bidang kerohanian, pendidikan, budaya, kesehatan, ekonomi, dan sosial. Kelancaran program kerja tersebut tidak lepas dari pendanaan yang bersumber dari infaq para jamaah. Jumlah jamaah 
Zahro, et al/Jurnal Ekonomi Syariah Teori dan Terapan Vol. 6 No. 6 Juni 2019: 1209-1227; ANALISIS THEORY OF PLANNED BEHAVIOUR DAN PENGETAHUAN TERHADAP NIAT BERINFAQ JAMAAH MAJELIS TAKLIM KECAMATAN SUKOMANUNGGAL SURABAYA

majelis taklim ini sebanyak 105 orang yang terdiri dari laki-laki dan perempuan, mulai usia remaja sampai lanjut usia. Jamaah juga terdiri dari yang sudah berpendapatan maupun belum berpendapatan. Sehubungan dengan uraian latar belakang diatas, maka penulis mencoba melakukan penelitian lebih lanjut mengenai Pengaaruh Sikap, Norma Subjektif, perceived behaviour control dan pengetahuan terhadap niat berinfaq jamaah Majelis Taklim Muhammadiyah Kecamatan Sukomanunggal Surabaya.

\section{Rumusan Masalah}

Berdasarkan latar belakang masalah yang telah diuraikan diatas, maka permasalahan yang dapat dirumuskan, adalah

1. Apakah sikap berpengaruh terhadap niat berinfaq jamaah majelis taklim Muhammadiyah Kecamatan Sukomanunggal Surabaya?

2. Apakah norma subjektif berpengaruh terhadap niat berinfaq jamaah majelis taklim Muhammadiyah Kecamatan Sukomanunggal Surabaya?

3. Apakah perceived behavior control berpengaruh terhadap niat berinfaq jamaah majelis taklim Muhammadiyah Kecamatan Sukomanungal Surabaya?

4. Apakah pengetahuan berpengaruh terhadap niat berinfaq jamaah majelis taklim Muhammadiyah Kecamatan Sukomanunggal Surabaya?

5. Apakah sikap, norma subjektif, perceived behavior control dan pengetahuan berpengaruh secara simultan terhadap niat berinfag jamaah majelis taklim Muhammadiyah Kecamatan Sukomanunggal Surabaya?

\section{LANDASAN TEOR}

Infaq

Kata Infaq berasal dari bahasa Arab yaitu anfaqo yang berarti megeluarkan sesuatu untuk kepentingan orang banyak. Infaq dalam Kamus Besar Bahasa Indonesia (KBBI) mempunyai arti pemberian (sumbangan) harta dan sebagainya (selain zakat wajib) untuk kebaikan. Menurut istilah, pengertian infaq adalah mengeluarkan sebagian dari harta atau pendapatan untuk suatu kepentingan yang diperintahkan ajaran Islam. Dengan demikian, infaq dapat diartikan sebagai harta atau pendapatan yang dikeluarkan yang mencakup zakat dan non zakat untuk kepentingan orang banyak yang diperintahkan oleh Allah SWT.

Infaq dijelaskan dalam Al-Qur'an surat Ali Imran ayat 134:

Artinya: "(yaitu) orang yang menafkahkan (hartanya), baik diwaktu lapang maupun sempit, dan orang-orang yang menahan amarahnya dan memaafkan (kesalahan) orang. Allah menyukai orang-orang yang berbuat kebajikan."

Berbeda dengan zakat, sesuai dengan firman Allah diatas, infaq tidak ditentukan nisabnya atau jumlah harta yang dikeluarkan. Infaq juga tidak diberikan kepada mustahik tertentu, 
Zahro, et al/Jurnal Ekonomi Syariah Teori dan Terapan Vol. 6 No. 6 Juni 2019: 1209-1227; ANALISIS THEORY OF PLANNED BEHAVIOUR DAN PENGETAHUAN TERHADAP NIAT BERINFAQ JAMAAH MAJELIS TAKLIM KECAMATAN SUKOMANUNGGAL SURABAYA

melainkan siapapun dapat menerimanya, misalkan kedua orangtua, anak yatim, saudara, teman, dan sebagainya. Infaq dikeluarkan oleh sesorang yang beriman, baik yang berpenghasilan tinggi maupun rendah dan dalam keadaan lapang maupun sempit. Dengan demikian, seseorang diberikan kebebasan oleh Allah untuk menentukan penerima infaq dan berapa jumlah harta yang akan diberikan dengan tujuan untuk kebaikan.

\section{Dasar Hukum Infaq}

Ada beberapa ayat Al-Qur'an yang menjadi dasar perintah Allah untuk berinfaq, yaitu QS. Adz-Dzariyat: 19, yang artinya: "Dan pada harta-harta mereka ada hak untuk orang miskin yang meminta dan orang miskin yanng tidak mendapat bagian". Ayat tesebut menjelaskan bahwa terdapat hak dari orang miskin yang terdapat pada hartaharta mereka. Hendaknya harta tersebut disisihkan dan diberikan kepada orangorang miskin.

Ada juga QS. Al-Baqarah: 245, yang artinya: "Siapakah yang mau memberi pinjaman kepada Allah, pinjaman yang baik (menafkahkan hartanya dijalan Allah), maka Allah akan memperlipat gandakan pembayaran kepadanya dengan lipat ganda yang banyak. Dan Allah menyempitkan dan melapangkan (rezeki) dan kepada-Nyalah kamu dikembalikan.

Ayat di atas menjelaskan bahwa Allah akan melipatgandakan harta yang dikeluarkan dijalan Allah, dan Allah akan melampangkan pintu rezekinya.

Dan juga QS. Al-Baqarah: 215, yang artinya: "Mereka bertanya tentang apa yang mereka nafkahkan. Jawablah: "Apa saja harta yang kamu nafkahkan hendaklah diberikan kepada ibu-bapak, kaum kerabat, anak-anak yatim, orangorang miskin, dan orang-orang yang sedang dalam perjalanan." Dan apa saja kebaikan yang kamu buat, Maka sesungguhnya Allah maha mengetahuinya."

Dari ayat-ayat Al-Qur'an diatas, dapat diketahui bahwa Allah SWT memerintahkan untuk mengeluarkan sebagian hartanya untuk diberikan kepada orang tua, kerabat, anak-anak yatim, orang-orang miskin dan orangorang yang sedang dalam perjalanan. Dan didalam harta-harta mereka terdapat hak dari orang miskin.

\section{Rukun dan Syarat Infaq}

Suatu perbuatan dikatakan sah, apabila unsur-unsur yang dimilikinya terpenuhi. Seperti halnya infaq, unsurunsur tersebut disebut rukun, dan dikatakan sah apabila apabila terpenuhi rukun-rukunnya, dan terdapat syarat yang harus terpenuhi di masing-masing rukun infaq. Menurut Al-Jazairi (2003:140), infaq memiliki 4 (empat) rukun, yaitu:

1. Penginfaq

$$
\text { Maksudnya yaitu orang yang }
$$
berinfaq, penginfaq tersebut harus memenuhi syarat-syarat berikut: 
a) Penginfaq memiliki apa yang diinfaqkan.

b) Penginfaq bukan orang yang dibatasi haknya karena suatu alasan.

c) Penginfaq itu orang dewasa, bukan anak yang kurang kemampuannya.

d) Penginfaq itu tidak dipaksa, sebab infaq itu akad yang mensyaratkan keridhaan dalam keabsahannya.

2. Orang yang diberi infaq

Maksudnya orang yang diberi infak oleh penginfaq, harus memenuhi syarat sebagai berikut:

a) Benar-benar ada waktu diberi infaq. Bila benar-benar tidak ada, atau diperkirakan adanya, misalnya dalam bentuk janin maka infaq tidak ada.

b) Dewasa atau baligh, maksudnya apabila orang yang diberi infag itu ada diwaktu pemberian infaq, akan tetapi ia masih kecil atau gila, maka infaq itu diambil oleh walinya, pemeliharaannya, atau orang yang mendidiknya, sekalipun dia orang asing.

3. Sesuatu yang diinfaqkan

Maksudnya orang yang diberi infaq oleh penginfaq, harus memenuhi syarat sebagai berikut:

a) Benar-benar ada

b) Harta yang bernilai

C) Dapat dimiliki zatnya, yakni bahwa yang diinfaqkan adalah apa yang biasanya dimiliki, diterima peredarannya, dan pemiliknya dapat berpindah tangan. Maka tiidak sah menginfaqkan air di sungai, ikan di laut, burung di udara.

d) Tidak berhubungan dengan tempat milik penginfaq, seperti menginfaqkan tanaman, pohon atau bangunan tanpa tanahnya. Akan tetapi yang diinfaqkan itu wajib dipisahkan dan diserahkan kepada yang diberi infaq sehingga menjadi milik baginya.

4. ljab dan Qabul

Infaq itu sah melalui ijab dan qabul, bagaianapun bentuk ijab qabul yang ditunjukkan oleh pemberian harta tanpa imbalan. Misalnya penginfaq berkata: "aku infaqkan kepadamu"; "aku berikan kepadamu"; atau yang serupa itu, sedang yang lain berkata: "Ya aku terima". Imam Malik dan Asy-Syafi'i berpendapat dipegangnya qabul didalam infaq. Sedangkan orang-orang Hanafi berpendapat bahwa ijab saja sudah cukup.

Niat

Pengertian niat menurut kamus besar bahasa Indonesia yaitu, niat adalah maksud atau tujuan suatu perbuatan, kehendak (keinginan dalam hati) akan melakukan sesuatu, dan janji untuk melakukan sesuatu jika cita-cita atau harapan terkabul; kaul; nazar. Selain itu menurut Ajzen (1991) Niat diasumsikan untuk menangkap faktor-faktor motivasional yang berdampak pada perilaku, merupakan indikasi seberapa keras seseorang berusaha, seberapa 
Zahro, et al/Jurnal Ekonomi Syariah Teori dan Terapan Vol. 6 No. 6 Juni 2019: 1209-1227; ANALISIS THEORY OF PLANNED BEHAVIOUR DAN PENGETAHUAN TERHADAP NIAT BERINFAQ JAMAAH MAJELIS TAKLIM KECAMATAN SUKOMANUNGGAL SURABAYA

banyak usaha yang mereka persiapkan untuk digunakan, agar menampilkan perilaku.

Menurut Schiffman dan Kanuk (1994) dalam Albari (2002) menyatakan bahwa motivasi sebagai kekuatan dorongan dari dalam diri individu yang memaksa mereka untuk melakukan tindakan. Jika seseorang mempunyai motivasi yang tinggi terhadap obyek tertentu, maka dia akan terdorong untuk berperilaku. Sebaliknya jika motivasinya rendah, maka dia akan mencoba untuk menghindari obyek yang bersangkutan.

Aspek-aspek Niat Menurut Fishbein dan Ajzen (1975: 292) niat memiliki empat aspek, yaitu:

1) Perilaku (behavior), yaitu perilaku spesifik yang nantinya akan diwujudkan.

2) Sasaran (target), yaitu objek yang menjadi sasaran perilaku. Objek yang menjadi sasaran dari perilaku spesifik dapat digolongkan menjadi tiga, yaitu orang atau objek tertentu (particular object), sekelompok orang atau objek (a class of object) dan orang atau objek pada umumnya (any object).

3) Situasi (situation), yaitu situasi yang mendukung untuk dilakukannya suatu perilaku (bagaimana dan dimana perilaku itu akan diwujudkan). Situasi dapat pula diartikan sebagai lokasi terjadinya perilaku.

4) Waktu (time), yaitu terjadinya perilaku yang meliputi waktu tertentu, dalam satu periode atau tidak terbatas misalnya waktu spesifik (hari tertentu, tanggal tertentu, jam tertentu), periode tertentu (bulan tertentu) dan waktu yang tidak terbatas (waktu yang akan datang).

\section{Sikap}

Ajzen (2005) mengemukakan bahwa sikap terhadap perilaku ditentukan oleh keyakinan mengenai konsekuensi dari suatu perilaku atau secara singkat disebut keyakinan-keyakinan perilaku (behavioral beliefs).

Ada empat definisi sikap. Pertama, bagaimana perasaan mereka terhadap obyek positif atau negatif, terima atau tidak terima, pro atau kontra. Kedua, sikap sebagai kecenderungan untuk merespon sebuah obyek atau golongan obyek dengan sikap yang secara konsisten menerima atau tidak menerima. Ketiga, sikap berorientasi pada psikologi sosial yaitu motivasi, emosi, persepsi, dan proses kognitif yang bertahan lama dengan beberapa aspek dari masing-masing individu. Keempat, keseluruhan sikap dari seseorang terhadap obyek dilihat dari fungsi kekuatan dari tiap-tiap sejumlah kepercayaan yang seseorang pegang tentang beberapa aspek dari obyek dan evaluasi yang diberikan dari tiap-tiap kepercayaan yang bersangkut paut pada obyek (Hanna, Nessim, dan Wozniak 2003).

\section{Norma Subjektif}

Norma subjektif mempunyai peran penting dalam menentukan kehendak atau niat seseorang untuk berperilaku. 
Zahro, et al/Jurnal Ekonomi Syariah Teori dan Terapan Vol. 6 No. 6 Juni 2019: 1209-1227; ANALISIS THEORY OF PLANNED BEHAVIOUR DAN PENGETAHUAN TERHADAP NIAT BERINFAQ JAMAAH MAJELIS TAKLIM KECAMATAN SUKOMANUNGGAL SURABAYA

Jogiyanto (2007) menyatakan bahwa intensi atau niat merupakan fungsi dari dua determinan dasar, yaitu sikap individu terhadap perilaku (merupakan aspek personal) dan persepsi individu terhadap tekanan sosial untuk melakukan atau untuk tidak melakukan perilaku yang disebut dengan norma subjektif. Setiap individu mempunyai pilihan untuk melakukan suatu tindakan yang dapat berakibat positif atau negatif bagi dirinya. Keputusan yang akan diambil dilakukan dengan pertimbangan sendiri maupun atas dasar pertimbangan orang lain yang dianggap penting. Keputusan yang diambil bisa gagal untuk dilakukan jika pertimbangan orang lain tidak mendukung, meskipun pertimbangan sendiri menguntungkan. Dalam hal ini, pertimbangan subjektif pihak lain (dalm penelitian ini, yaitu ustad atau ulama) dapat memberikan dorongan kepada majelis taklim untuk berinfaq.

Teori Norma Subjektif menurut Budiman (2014), Norma Subjektif mengandung dua aspek utama yaitu referensi norma harapan, adalah pandangan sisi lain yang dianggap penting oleh individu yang menunjukkan individu untuk hadir atau tidak hadir pada perilaku tertentu dan individu memotivasi kemauan untuk melakukan atau tidak melakukan pendapat pihak lain atau pikiran yang dianggap penting individu yang harus atau tidak harus berperilaku. Mowen dan Minor (2002) menyatakan bahwa, norma subjektif merupakan komponen yang berisikan keputusan yang dibuat oleh individu, setelah mempertimbangkan pandangan orang lain yang mempengaruhi perilaku. Dengan demikian, norma subjektif mengacu pada tekanan sosial yang dirasakan untuk terlibat dalam perilaku atau tidak.

Perceived Behaviour Control / Kontrol Perilaku Persepsian

Persepsi kontrol perilaku atau dapat disebut dengan kontrol perilaku adalah persepsi individu mengenai mudah atau sulitnya mewujudkan suatu perilaku tertentu (Ajzen, 2005). Dengan kata lain kontrol perilaku menunjuk kepada sejauh mana seseorang merasa bahwa menampilkan atau tidak menampilkan perilaku tertentu berada di bawah kontrol individu yang bersangkutan. Kontrol perilaku ditentukan oleh sejumlah keyakinan tentang hadirnya faktor-faktor yang dapat memudahkan atau mempersulit terlaksananya perilaku yang ditampilkan. Perilaku adalah semua kegiatan atau aktivitas manusia, baik yang dapat diamati langsung maupun yang tidak dapat diamati oleh pihak luar. Perilaku merupakan respons atau reaksi seseorang terhadap stimulus rangsangan dari luar (Notoatmodjo, 2003). Di banyak contoh, kinerja dari suatu perilaku tergantung tidak hanya pada motivasi untuk melakukannya tetapi juga kontrol yang cukup terhadap perilaku yang dilakukan. Dengan demikian. Kontrol perilaku persepsian (perceived behavioral 
Zahro, et al/Jurnal Ekonomi Syariah Teori dan Terapan Vol. 6 No. 6 Juni 2019: 1209-1227; ANALISIS THEORY OF PLANNED BEHAVIOUR DAN PENGETAHUAN TERHADAP NIAT BERINFAQ JAMAAH MAJELIS TAKLIM KECAMATAN SUKOMANUNGGAL SURABAYA

control) dapat mempengaruhi perilaku secara tidak langsung lewat minat, dan juga dapat memprediksi perilaku secara langsung.

Kontrol perilaku secara langsung mempengaruhi niat untuk melaksanakan suatu perilaku dan juga mempengaruhi perilaku (Ajzen, 2006). Di mana dalam situasi pengguna berniat untuk melaksanakan suatu perilaku namun dihalangi dalam melakukan tindakan tersebut. Kontrol perilaku yang dirasakan ditunjukan dengan tanggapan seseorang terhadap halangan dari dalam atau halangan dari luar sewaktu melakukan perilaku atau tingkah laku. Kontrol perilaku dapat mengukur kemampuan seseorang dalam mendapatkan sesuatu dalam mengambil suatu kegiatan.

\section{Pengetahuan}

Pengetahuan menurut Kamus Besar Bahasa Indonesia berarti segala sesuatu yang diketahui, kepandaian. Menurut Pudjawidjana (1983), pengetahuan adalah reaksi dari manusia atas rangsangannya oleh alam sekitar melalui persentuhan melaui objek dengan indra dan pengetahuan merupakan hasil yang terjadi setelah orang melakukan penginderaan sebuah objek tertentu.

Menurut Notoadmodjo (2003), pengetahuan merupakan hasil dari tahu, dan ini terjadi setelah orang melakukan pengindraan terhadap suatu objek tertentu. Pengindraan terjadi melalui panca indra manusia yakni indra penglihatan, pendengaran, penciuman, rasa, dan raba. Sebagian besar pengetahuan manusia diperoleh melalui mata dan telinga.

Dari uraian diatas dapat disimpulkan bahwa pengetahuan merupakan segala sesuatu yang diketahui yang diperoleh dari persentuhan panca indra terhadap objek tertentu. Pengetahuan pada dasarnya merupakan hasil dari proses melihat, mendengar, merasakan, dan berpikir yang menjadi dasar manusia bersikap dan bertindak.

IImu atau pengetahuan dalam Islam dijelaskan pada Al-Qur'an surat Al-Isra ayat 36 yang berbunyi:

Artinya: "Dan janganlah engkau turut apa-apa yang engkau tidak ada ilmu padanya, sesungguhnya pendengaran, penglihatan dan hati, semuanya akan ditanya."

Ayat Al-Qur'an tersebut menjelaskan bahwa ilmu atau pengetahuan merupakan dasar dari segala tindakan manusia, karena tanpa ilmu segala tindakan manusia menjadi tidak terarah, tidak benar, dan tidak bertujuan. Dengan pengetahuan inilah manusia melakukan perbuatan amalnya. Jika manusia memiliki ilmu tetapi tidak beramal, maka ilmu tersebut akan sia-sia.

\section{Hipotesis}

Berdasarkan rumusan masalah yang telah dijelaskan, maka ada lima hipotesis dalam penelitian ini, sebagai berikut:

H1: Ada pengaruh sikap terhadap niat berinfaq jamaah majelis taklim 
Zahro, et al/Jurnal Ekonomi Syariah Teori dan Terapan Vol. 6 No. 6 Juni 2019: 1209-1227; ANALISIS THEORY OF PLANNED BEHAVIOUR DAN PENGETAHUAN TERHADAP NIAT BERINFAQ JAMAAH MAJELIS TAKLIM KECAMATAN SUKOMANUNGGAL SURABAYA

Muhammadiyah Kecamatan

Sukomanunggal Surabaya

H2: Ada pengaruh norma subjektif terhadap niat berinfaq jamaah majelis taklim Muhammadiyah di Kecamatan Sukomanungal Surabaya

H3: Ada pengaruh perceived behavior cotrol terhadap niat berinfaq jamaah majelis taklim Muhammadiyah Kecamatan Sukomanungal Surabaya

H4: Ada pengaruh pengetahuan terhadap niat berinfaq jamaah majelis taklim Muhammadiyah di Kecamatan Sukomanunggal Surabaya

H5: Ada pengaruh secara simultan antara sikap, norma subjektif, perceived behaviour controldan pengetahuan terhadap niat berinfaq jamaah majelis taklim Muhammadiyah di Kecamatan Sukomanunggal Surabaya

\section{METODE PENELITIAN}

\section{Definisi Operasional Variabel}

Dalam penelitian pengaruh sikap, norma subjektif, perceived behaviour control dan pengetahuan terhadap niat berinfaq jamaah majelis taklim Muhammadiyah Surabaya Kecamatan Sukomanunggal, diketahui variabel eksogennya yaitu sikap, norma subjektif, perceived behaviour control dan pengetahuan, sedangakn variabel endogennya yaitu niat berinfaq jamaah majelis taklim.
Sikap

Ajzen (2005) menjelaskan bahwa sikap di definisikan sebagai disposisi atau kecenderungan untuk menanggapi halhal yang bersifat evaluatif, disenangi, atau tidak disenangi terhadap objek, orang, institusi, atau peristiwa sehingga menjurus pada penerimaan atau penolakan perilaku tersebut. Sikap yang di teliti dalam penelitian ini adalah pandangan jamaah Majelis Taklim Muhammadiyah Kecamatan Sukomanunggal mengenai perilaku berinfaq untuk menerima atau menolaknya.

Indikator yang digunakan dalam penelitian ini merujuk pada penjelasan dari Marchus dan Purwono (2010), Mahyarni (2013), dan penelitian Osman (2014) yang kemudian dimodifikasi dan disesuaikan dengan kondisi di lapangan sehingga indikatornya adalah sebagai berikut:

1. Jamaah Majelis Taklim percaya bahwa berinfaq adalah perbuatan yang baik.

2. Jamaah Majelis Taklim percaya bahwa infaq bermanfaat bagi diri saya dan masyarakat luas.

3. Dengan menunaikan Infaq, Jamaah Majelis Taklim percaya akan memperoleh keberkahan dalam kehidupan.

Skala Likert menurut Sugiyono (2014: 93) digunakan untuk mengukur sikap, pendapat, dan persepsi seseorang atau sekelompok orang tentang fenomena sosial. Variabel sikap dalam penelitian ini akan diukur dengan skala 
Zahro, et al/Jurnal Ekonomi Syariah Teori dan Terapan Vol. 6 No. 6 Juni 2019: 1209-1227; ANALISIS THEORY OF PLANNED BEHAVIOUR DAN PENGETAHUAN TERHADAP NIAT BERINFAQ JAMAAH MAJELIS TAKLIM KECAMATAN SUKOMANUNGGAL SURABAYA

Likert yang terdiri dari empat tingkat. Kriteria pemberian skor setiap item untuk setiap jawaban sebagai berikut:

1 = Sangat tidak setuju

2 = Tidak setuju

3 = Setuju

4 = Sangat Setuju

\section{Norma Subjektif}

Norma subjektif dalam penelitian ini adalah persepsi Jamaah majelis taklim tentang tekanan sosial untuk melakukan atau tidak melakukan perilaku berinfaq. Tekanan sosial tersebut berasal dari orangorang disekitar majelis taklim seperti keluarga, teman, dan orang atau tokoh yang dianggap penting..

Indikator yang digunakan untuk mengukur norma subyektif merujuk pada penjelasan dari Purwono (2010) yang kemudian di modifikasi dan di sesuaikan dengan kondisi di lapangan sehingga indikatornya adalah sebagai berikut:

1. Mayoritas orang-orang penting bagi jamaah majelis taklim (keluarga, kerabat, teman, dan lain lain) meyarankan majelis taklim untuk menunaikan infag

2. Mayoritas orang-orang penting bagi jamaah majelis taklim (keluarga, kerabat, teman, dan lain lain) memandang infag adalah hal yang baik

3. Mayoritas orang-orang penting bagi jamaah majelis taklim (keluarga, kerabat, teman, dan lain lain) berfikir bahwa majelis taklim akan

menunaikan infaq.

Pengukuran variabel norma subjektif dalam penelitian ini menggunakan skala likert, namun menghilangkan nilai tengah/netral sehingga hanya terdapat empat poin yaitu:

1. sangat tidak setuju

2. tidak setuju

3. setuju

4. sangat setuju

Perceived Behaviour Control

Ajzen (2005) Kontrol perilaku yang dipersepsikan adalah kemudahan dan kesulitan yang diyakini sesorang untuk melakukan suatu perilaku sehingga mempengaruhinya untuk menerima atau menolak perilaku tersebut. Kontrol perilaku yang dipersepsikan yang diteliti dalam penelitian ini adalah persepsi jamaahMajelis Taklim Muhammadiyah Kecamatan Sukomanunggal mengenai kemudahan atau kesulitan untuk menunaikan infaq.

Indikator yang digunakan dalam penelitian merujuk padapenjelasan dari Marchus dan Purwono (2010), Mahyarni (2013), dan penelitian Osman (2014) yang kemudian dimodifikasi dan disesuaikan dengan kondisi di lapangan sehingga indikatornya adalah sebagai berikut:

1. Jamaah taklim memiliki keuangan yang cukup yang dapat digunakan untuk berinfaq.

2. Melakukan infaq dalam kendali atau kontrol diri jamaahmajelis taklim. 
Zahro, et al/Jurnal Ekonomi Syariah Teori dan Terapan Vol. 6 No. 6 Juni 2019: 1209-1227; ANALISIS THEORY OF PLANNED BEHAVIOUR DAN PENGETAHUAN TERHADAP NIAT BERINFAQ JAMAAH MAJELIS TAKLIM KECAMATAN SUKOMANUNGGAL SURABAYA

3. Jamaah Taklim merasa memiliki banyak kesempatan untuk menunaikan infaq.

Pengukuran variabel perceived behaviour controldalam penelitian ini menggunakan skala likert, namun menghilangkan nilai tengah/netral sehingga hanya terdapat empat poin yaitu:

1. sangat tidak setuju

2. tidak setuju

3. setuju

4. sangat setuju

\section{Pengetahuan}

Pengetahuan dalam penelitian ini, yaitu banyaknya informasi yang dimiliki oleh majelis taklim mengenai infaq. Kedalaman pengetahuan responden yang ingin diukur atau diketahui, dapat disesuaikan dengan tingkat pengetahuan dari responden. Menurut Notoatmodjo (2003) pengetahuan tercakup dalam domain kognitif mempunyai enam tingkatan yakni: tahu, memahami, aplikasi, analisis, sintesis dan evaluasi.

Pengukuran variabel pengetahuan dalam penelitian ini menggunakan skala likert, namun menghilangkan nilai tengah/netral sehingga hanya terdapat empat poin yaitu:

1. sangat tidak setuju

2. tidak setuju

3. setuju

4. sangat setuju

Niat

Ajzen (2005) menjelaskan bahwa niat adalah niat berarti maksud dan tujuan suatu perbuatan (kehendak/keinginan dalam hati akan melakukan sesuatu); janji untk melakukan sesuatu apabila cita cita dan harapan terkabul. Dalam penelitian ini niat yang dimaksud adalah niat berinfaq majelis taklim. Indikator yang digunakan untuk mengukur niat dalam penelitian ini merujuk pada teori yang dikemukakan Ajzen (2005) yang kemudian disesuaikan dengan kondisi lapangan sehingga indikatornya adalah sebagai berikut:

1. Jamaah Majelis taklim berniat menunaikan infaq di masa yang akan dating

2. Jamaah Majelis taklim berencana untuk menunaikan infaq

3. Jamaah Majelis taklim memilih infaq sebagai salah satu cara untuk beramal.

Pengukuran variabel niat dalam penelitian ini menggunakan skala likert, namun menghilangkan nilai tengah/netral sehingga hanya terdapat empat poin (Azwar, 1997), yaitu:

1. sangat tidak setuju

2. tidak setuju

3. setuju

4. sangat setuju

\section{Prosedur Pengumpulan Data}

\section{Populasi Penelitian}

Menurut Arikunto (1998), dalam Arifin, (2014:34) Populasi adalah semua nilai hasil perhitungan dan pengukuran, baik kuantitatif maupun kualitatif pada karakteristik tertentu mengenai sekelompok objek yang lengkap dan jelas. Dengan kata lain, populasi adalah 
Zahro, et al/Jurnal Ekonomi Syariah Teori dan Terapan Vol. 6 No. 6 Juni 2019: 1209-1227; ANALISIS THEORY OF PLANNED BEHAVIOUR DAN PENGETAHUAN TERHADAP NIAT BERINFAQ JAMAAH MAJELIS TAKLIM KECAMATAN SUKOMANUNGGAL SURABAYA

keseluruhan subyek penelitian. Populasi dalam peneliti adalah seluruh jamaah majelis taklim Kecamatan Sukomanunggal Surabaya.

\section{Karakteristik Sampel}

Sampel adalah bagian dari jumlah dan karakteristik yang dimiliki oleh populasi tersebut (Sugiyono, 2015:81). Karakteristik sampel dalam penelitian ini adalah seluruh jamaah majelis taklim Kecamatan Sukomanunggal Surabaya yang mengikuti pengajian. Teknik Pengambilan Sampel teknik yang digunakan adalah Non Propability Sampling dan Accidential Sampling. Hal ini dikarenakan bahwa jamaah taklim yang mengikuti pengajian dalam satu waktu tidak dapat ditentukan jumlahnya. Ada diantara mereka yang mengikuti secara aktif dan ada yang tidak. Jumlah sampel dalam penelitian ini adalah 40 responden. Jumlah ini ditetapkan berdasarkan perhitungan 10 kali jumlah variabel. Rescoe (1975, dalam Sekaran, 2006) menjelaskan bahwa dalam penelitian multivariate, ukuran sampel sebaiknya 10 kali lebih besar dari jumah variabel. Metode pengambilan sampel yang digunakan adalah gabungan antara accidental sampling dan purposive sampling. Penulis menggunakan accidental sampling yaitu pengambilan sampel berdasarkan kemudahan dimana penulis akan mengambil jamaah taklim sebagai sampel berdasarkan kemudahan bertemu dan berinteraksi dengan jamaah taklim yang dianggap sesuai untuk menjadi responden dengan tidak memberikan batasan berapa jumlah responden yang ditemui hingga berjumlah 40 responden. Purposive samplingdigunakan untuk menemukan sampel dengan maksud dan tujuan tertentu yang dianggap memiliki informasi yang diperlukan untuk penelitian ini.

\section{Metode Pengumpulan Data}

Metode pengumpulan data yang digunakan dalam penelitian ini adalah kuesioner dan dokumentasi.

\section{Uji Kualitas Data}

\section{Uji Validitas}

Menurut Sugyiono (2015:121), Instrumen yang valid berarti alat ukur yang digunakan untuk mendapatkan data (mengukur) itu valid. Yang berarti dapat digunakan untuk mengukur apa yang seharusnya diukur. Nilai $r$ hitung diperoleh dari hasil uji validitas dengan SPSS pada kolom corrected item-total correlation. Nilai $r$ tabel ditentukan berdasarkan rumus $\mathrm{df}=\mathrm{n}-2$ dengan tingkat signifikansi sebesar 5\%. Data kuesioner dapat dikatan valid jika nilai $r$ hitung $>r$ tabel.

\section{Uji Reliabilitas}

Sekaran (2006) menjelaskan bahwa uji reliabilitas ditujukan uuntuk membuktikan konsistensi dan stabilitas instrumen pengukuran. Selanjutnya Ghozali (2009) menyatakan bahwa suatu variabel dikatakan reliable jika memberikan nilai Cronbach Alfa $>0,60$

\section{Teknik Analisis Data}

Uji Asumsi Klasik 
Zahro, et al/Jurnal Ekonomi Syariah Teori dan Terapan Vol. 6 No. 6 Juni 2019: 1209-1227; ANALISIS THEORY OF PLANNED BEHAVIOUR DAN PENGETAHUAN TERHADAP NIAT BERINFAQ JAMAAH MAJELIS TAKLIM KECAMATAN SUKOMANUNGGAL SURABAYA

Model regresi linear berganda dapat disebut sebaga model yang baik jika memenuhi beberapa asumsi klasik. Proses pengujian asumsi klasik dilakukan bersama dengan proses uji regresi sehingga langkahlangkah yang dilakukan dalam pengujian asumsi klasik menggunankan langkah kerja yang sama dengan uji regresi yaitu :

\section{Multikolinieritas}

Model regresi yang baik seharusnya tidak terjadi korelasi di antara variabel bebas (Ghozali, 2009). Multikolinearitas tidak terjadi apabila nilai tolerance lebih besar dari 0,1 dan nilai Variance Inflation Factor (VIF) lebih kecil dari 10 atau di sekitar angka 1 (satu).

\section{Uji Normalitas}

Ghozali (2005) menjelaskan uji normalitas bertujuan untuk menguji apakah dalam model regresi variabel endogen dan eksogen keduanya mempunyai distribusi normal atau tidak. Dasar pengambilan keputusan melalui pertimbangan jika data menyebar disekitar garis diagonal dan mengikuti garis diagonal atau grafik histogram menunjukan pola terdistribusi normal (Ghozali, 2005).

\section{Uji Heteroskedastisitas}

Uji heteroskedastisitas bertujuan menguji apakah dalam model regresi terjadi ketidaksamaan variance dari residual dalam satu pengamatan ke pengamatan yang lain (Ghozali, 2005). Salah satu cara untuk pengujian heterokedasitas adalah dengan menggunakan grafik scatterplot yang terdapat pada menu SPSS yaitu antara lain prediksi variabel tergantung (ZPRED) dengan nilai residualnya (SRESID). Persamaan Regresi Linear Berganda Adapun persamaan untuk menguji hipotesis secara keseluruhan pada penelitian ini adalah sebagai berikut:

Persamaan Regresi:

$$
Y=\beta 0+\beta 1 X 1+\beta 2 X 2+\beta 2 X 3 \text { e.....(1) }
$$

Keterangan

Y : Niat Berinfaq Pedagang Muslim Pasar Tradisional
X1: Sikap
X2 : Norma Subyektif
X3 : Perceived Behavior Control
$\mathrm{X} 4$ : Pengetahuan
e : Standar error

\section{Koefisien Determinasi $\left(\mathbf{R}^{2}\right)$}

Koefisien Determinasi $\left(R^{2}\right)$ untuk mengukur seberapa jauh kemampuan model dalam menjelaskan variasi variabel dependen. Niai koefisien determinasi berada di antara nol dan satu. Nilai $R^{2}$ yang kecil berarti kemampuan variabelvariabel independen dalam menjelaskan variabel dependen sangat terbatas. Nilai $R^{2}$ yang besar berarti variabel-variabel independen dianggap mampu menjelaskan variabel dependen (Ghozali, 2009: 43).

\section{Uji Hipotesis}

\section{Uji Signifikansi Simultan (Uji F)}

Uji statistik $F$ pada dasarnya menunjukkan apakah semua variabel bebas yang dimaksudkan dalam model mempunyai pengaruh secara simultan 
Zahro, et al/Jurnal Ekonomi Syariah Teori dan Terapan Vol. 6 No. 6 Juni 2019: 1209-1227; ANALISIS THEORY OF PLANNED BEHAVIOUR DAN PENGETAHUAN TERHADAP NIAT BERINFAQ JAMAAH MAJELIS TAKLIM KECAMATAN SUKOMANUNGGAL SURABAYA

terhadap variabel dependen. Pengujian dilakukan dengan menggunakan significance level 0,05 ( $a=5 \%$ )(Ghozali, 2009)

Uji Signifikansi Parameter Individual (Uji †)

Uji statistik $†$ pada dasarnya menunjukkan seberapa jauh pengaruh satu variabel independen secara individual dalam menerangkan variabel dependen. Pengujian dilakukan dengan menggunakan significance level 0,05 ( $a=5 \%$ ). (Ghozali, 2009: 45)

IV. HASIL DAN PEMBAHASAN

Uji Validitas

Tabel 1.

Hasil Uji Validitas

\begin{tabular}{|c|c|c|c|}
\hline Item & $\begin{array}{l}\text { Corrected } \\
\text { Item-Total } \\
\text { Correlation }\end{array}$ & $R$ tabel & Ket \\
\hline \multicolumn{4}{|c|}{ Sikap } \\
\hline $\mathrm{X} 1.1$ & 0,613 & 0,312 & Valid \\
\hline $\mathrm{X} 1.2$ & 0,701 & 0,312 & Valid \\
\hline $\mathrm{X} 1.3$ & 0,588 & 0,312 & Valid \\
\hline $\mathrm{X} 1.4$ & 0,554 & 0,312 & Valid \\
\hline$\times 1.5$ & 0,522 & 0,312 & Valid \\
\hline $\mathrm{X} 1.6$ & 0,408 & 0,312 & Valid \\
\hline \multicolumn{4}{|c|}{ Norma Subjektif } \\
\hline $\mathrm{X} 2.1$ & 0,798 & 0,312 & Valid \\
\hline $\mathrm{X} 2.2$ & 0,761 & 0,312 & Valid \\
\hline X2.3 & 0,844 & 0,312 & Valid \\
\hline$\times 2.4$ & 0,438 & 0,312 & Valid \\
\hline$\times 2.5$ & 0,586 & 0,312 & Valid \\
\hline \multicolumn{4}{|c|}{ Perceived Behaviour Control } \\
\hline$\times 3.1$ & 0,46 & 0,312 & Valid \\
\hline$\times 3.2$ & 0,49 & 0,312 & Valid \\
\hline X3.3 & 0,572 & 0,312 & Valid \\
\hline \multicolumn{4}{|c|}{ Pengetahuan } \\
\hline X4.1 & 0,625 & 0,312 & Valid \\
\hline
\end{tabular}

\begin{tabular}{|c|c|c|c|}
\hline X4.2 & 0,667 & 0,312 & Valid \\
\hline X4.3 & 0,667 & 0,312 & Valid \\
\hline X4.4 & 0,374 & 0,312 & Valid \\
\hline X4.5 & 0,567 & 0,312 & Valid \\
\hline X4.6 & 0,524 & 0,312 & Valid \\
\hline \multicolumn{4}{|c|}{ Niat } \\
\hline Y1.1 & 0,497 & 0,312 & Valid \\
\hline Y1.2 & 0,558 & 0,312 & Valid \\
\hline Y1.3 & 0,335 & 0,312 & Valid \\
\hline
\end{tabular}

Berdasarkan tabel diatas, menunjukkan bahwa seluruh indikator pada masing-masing variabel dengan 40 responden adalah valid. Seluruh indikator menunjukkan nilai corrected item-total correlation lebih dari r Tabel $(0,312)$.

Uji Reliabilitas

Tabel 2.

Hasil Uji Reliabilitas

\begin{tabular}{|l|r|l|}
\hline \multicolumn{1}{|c|}{ Variabel } & \multicolumn{1}{c|}{ Alpha } & Ket. \\
\hline Sikap & 0,796 & Reliabel \\
\hline Norma Subjektif & 0,862 & Reliabel \\
\hline $\begin{array}{l}\text { Perceived behaviour } \\
\text { control }\end{array}$ & 0,691 & Reliabel \\
\hline Pengetahuan & 0,794 & Reliabel \\
\hline Niat Berinfaq & 0,646 & Reliabel \\
\hline
\end{tabular}

Berdasarkan tabel di atas, menunjukkan bahwa seluruh indikator pada masing-masing variabel dengan 40 responden adalah reliabel. Seluruh indikator menunjukkan nilai Cronbach Alfa lebih dari 0,60.

Uji Asumsi Klasik

Uji Normalitas 


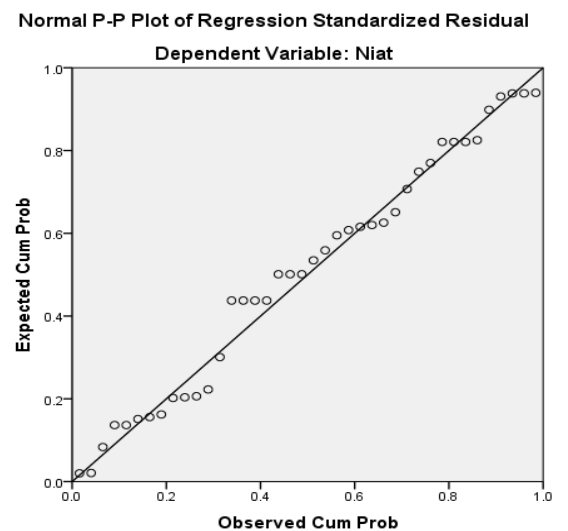

Gambar 1.

Normal Probability Plot

Pengujian normalitas dilakukan dengan menggunakan pengujian grafik normal $p$-p plot of regression standardized residual. Hasil penelitian menunjukkan bahwa data menyebar di sekitar garis diagonal dan mengikuti arah atau mendekati garis diagonal. Berdasarkan hal tersebut maka model regresi terdistribusi normal.

Uji Multikolinieritas

Tabel 3.

Hasil Uji Multikolinieritas

\begin{tabular}{|l|r|c|}
\hline \multicolumn{1}{|c|}{ Model } & Tolerance & VIF \\
\hline Sikap & 0,197 & 5,074 \\
\hline Norma Subjektif & 0,255 & 3,924 \\
\hline $\begin{array}{l}\text { Perceived behaviour } \\
\text { control }\end{array}$ & 0,205 & 4,870 \\
\hline Pengetahuan & 0,239 & 4,179 \\
\hline Variabel Endogen : Niat Berinfaq \\
\hline
\end{tabular}

Uji multikoinieritas dapat dilakukan dengan melihat nilai tolerance serta Variance Inflation Factor (VIF), multikolinieritas tidak terjadi apabila nilai tolerance lebih besar dari 0,1 dan nilai Variance Inflation Factor (VIF) lebih kecil dari 10 atau disekitar angka 1. Berdasarkan tabel di atas, nilai tolerance lebih besar dari 0,1 dan nilai variance inflation factor (VIF) lebih kecil dari 10 atau di sekitar angka 1. Sehingga variabel dalam dalam penelitian ini tidak terjadi korelasi antara variabel eksogen.

\section{Uji Heterokesdatisitas}

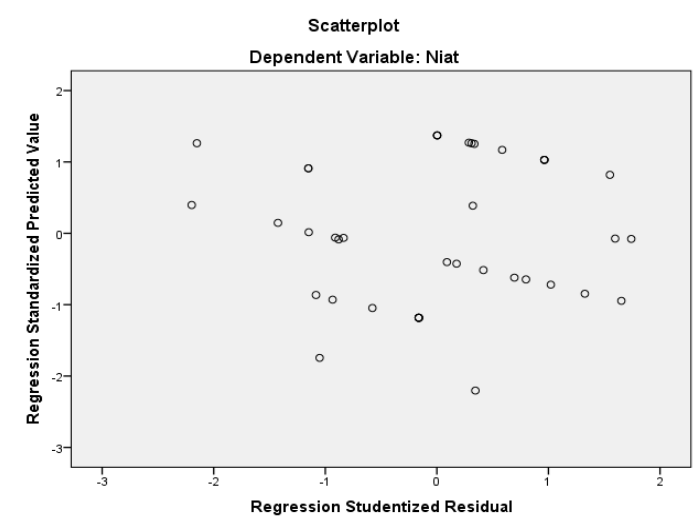

Gambar 2.

\section{Hasil Uji Heterokesdatisitas}

Uji heterokesdatisitas dilihat melalui grafik scatterplot SRESID dan ZPRED di atas, dimana sumbu $Y$ adalah $Y$ yang telah diprediksi, dan sumbu $X$ adalah residual ( $Y$ prediksi - $Y$ sesungguhnya). Hasil penelitian menunjukkan bahwa tidak ada pola yang jelas, serta titiktitik penyebaran berada di atas dan di bawah angka $O$ (nol) pada sumbu $Y$, berdasarkan hal tersebut maka tidak terjaddi heterokedastisitas.

\section{Analisis regresi Linear Berganda}

$$
Y=0,91+0,250 \times 1+0,227 \times 2+
$$

$$
0,267 \times 3+0,232 \times 4
$$

\section{Keterangan}

$Y=$ Niat Berinfaq

$\mathrm{X} 1=$ Sikap

$\mathrm{X} 2=$ Norma Subjektif

X3 $=$ Perceived Behaviour Control 
Zahro, et al/Jurnal Ekonomi Syariah Teori dan Terapan Vol. 6 No. 6 Juni 2019: 1209-1227; ANALISIS THEORY OF PLANNED BEHAVIOUR DAN PENGETAHUAN TERHADAP NIAT BERINFAQ JAMAAH MAJELIS TAKLIM KECAMATAN SUKOMANUNGGAL SURABAYA

X4 = Pengetahuan

Dari hasil analisis regresi linear berganda diatas diperoleh $t$ dan tingkat sgnifikansi dari masing masing variabel eksogen sebagai berikut :

1. Sikap (X1) memperoleh nilai $t$ sebesar 2.040 dan tingkat signifikansi 0.049

2. Norma Subjektif (X2) memperoleh nilai † sebesar 2.257 dan tingkat signifikansi 0.030

3. Perceived behaviour control (X3) memperoleh nilai $\dagger$ sebesar 2.152 dan tingkat signifikansi 0.038

4. Pengetahuan (X4) memperoleh nilai $†$ sebesar 2.156 dan tingkat signifikansi 0,038

\section{Koefisien Determinan $\left(\mathbf{R}^{2}\right)$}

Tabel 4.

\section{Koefisien Determinasi}

\begin{tabular}{|c|}
\hline Koefisien Determinasi $\left(R^{2}\right)$ \\
\hline 0,889 \\
\hline
\end{tabular}

Besarnya sumbangan variabel dalam penelitian ini dapat dilihat dari nilai koefisien determinasi ( $R$ Square) sebesar 0,889 atau $88,9 \%$. Dapat diartikan bahwa $88,9 \%$ variasi variabel niat berinfaq ( $Y$ ) pada model regresi penelitian ini dapat dijelaskan oleh variabel bebas yang terdiri dari variabel sikap (X1), norma subjektif (X2), perceived behaviour control (X3), dan pengetahuan (X4). Sedangkan sisanya $11,1 \%$ ( $100 \%-88,9 \%$ ) dipengaruhi oleh variabel lain diluar variabel yang digunakan dalam penelitian ini.

Uji Hipotesis

Uji Signifikansi Simultan (Uji F)
Tabel 5.

\section{Hasil Uji Signifikansi Simultan (Uji F)}

\begin{tabular}{|c|l|}
\hline Nilai F & Sig \\
\hline 69,824 & $0.000^{\mathrm{b}}$ \\
\hline
\end{tabular}

Hasil F-hitung sebesar 69,824 dengan nilai signifikansi sebesar 0,000 . Nilai signifikansi tersebut lebih kecil dari 0,05.Berdasarkan hal tersebut, dapat disimpulkan bahwa terdapat pengaruh secara simultan antara sikap, norma subjektif, perceived behaviour control, dan pengetahuan secara simultan terhadap niat berinfaq majelis taklim Muhammadiyah

Kecamatan

Sukomanunggal Kota Surabaya.

Uji Signifikansi Parameter Individual (Uji t)

Tabel 6.

Hasil Uji Signifikansi Parameter Individual

(Uji t)

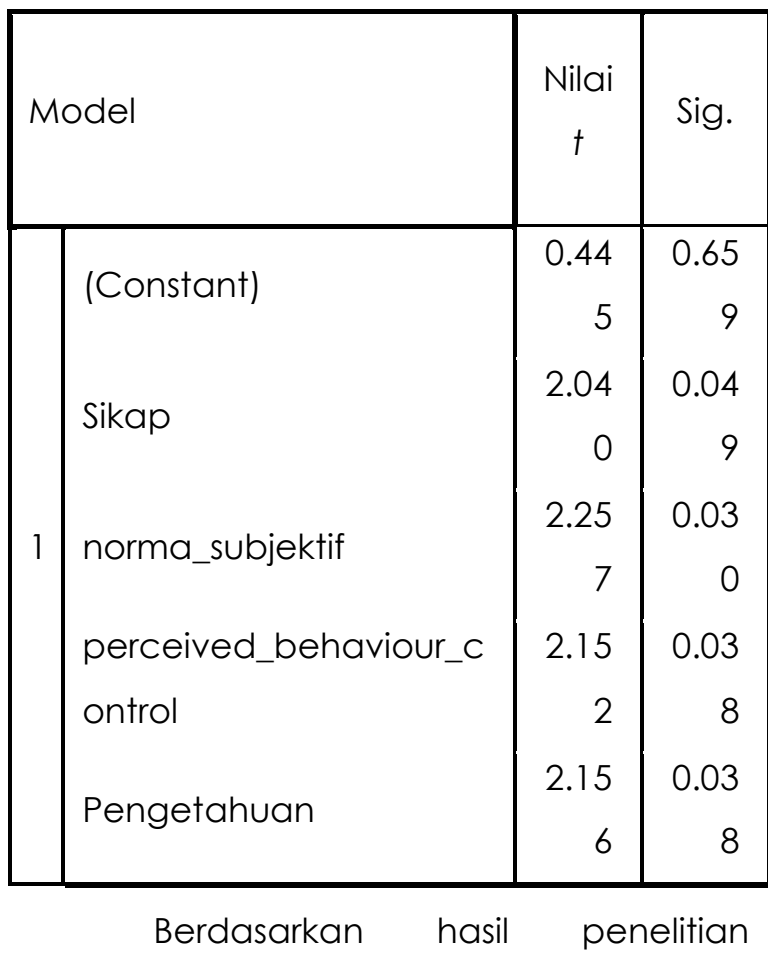

diperoleh uji signifikansi parameter individual mengenai pengaruh sikap, norma subjektif, perceived behaviour 
Zahro, et al/Jurnal Ekonomi Syariah Teori dan Terapan Vol. 6 No. 6 Juni 2019: 1209-1227; ANALISIS THEORY OF PLANNED BEHAVIOUR DAN PENGETAHUAN TERHADAP NIAT BERINFAQ JAMAAH MAJELIS TAKLIM KECAMATAN SUKOMANUNGGAL SURABAYA

control, dan pengetahuan secara parsial terhadap niat berinfaq majelis taklim Muhammadiyah Kecamatan Sukomanunggal Surabaya kurang dari 0,05 sehingga semua variabel bebas berpengaruh terhadap variabel teriikat.

\section{KESIMPULAN}

Kesimpulan penelitian pengaruh sikap, perceived behaviour control, norma subyektif, dan pengetahuan terhadap niat berinfaq majelis taklim Muhammadiyah Kec. Sukomanunggal adalah sebagai berikut.

1. Sikap, Percieved Behaviour Control, norma subyektif, dan pengetahuan secara simultan berpengaruh positif signifikan terhadap niat berinfaq majelis taklim Muhammadiyah Kec. Sukomanunggal Kota Surabaya.

2. Sikap secara parsial berpengaruh positif signifikan terhadap niat berinfaq majelis taklim Muhammadiyah Kec. Sukomanunggal Kota Surabaya.

3. Perceived Behaviour Control secara parsial berpengaruh positif signifikan terhadap niat berinfaa majelis taklim Muhammadiyah Kec. Sukomanunggal Kota Surabaya.

4. Norma Subjektif secara parsial berpengaruh positif signifikan terhadap niat berinfaq majelis taklim Muhammadiyah Kec. Sukomanunggal Kota Surabaya.

5. Pengetahuan secara parsial berpengaruh positif signifikan terhadap niat berinfaq majelis taklim Muhammadiyah Kec. Sukomanunggal Kota Surabaya.

\section{DAFTAR PUSTAKA}

Abd Al-Rahman Al-Jazairi, Al-Fiqh 'Ala AlMadzahib Al-'Arba'ah, (Bairut: Dar Al-Kutub Al-IImiyah, 2003), Juz. II, 140.

Ajzen, I (1991).The Theory of Planned Behavior" Organizational Behavior and Human Decission Processes. Vol.50 No.2, PP179-211

Ajzen, I (2005).Attitudes, Personality and Behavior.2nd Edition. Open University Press, New York. N.Y

Ajzen, I. 1985. Attitude, Personality and Behavior. Open University Press :Milton keynes

Albari, 2002, Mengenal Perilaku Konsumen Melalui Penelitian Motivasi. Jurnal Siasat Bisnis Vol 1, No 7 (2002)

Anwar, K.; Abu Bakar.; Harmaini. 2005. Hubungan antara Komitmen Beragama dengan Intensi Prososial Mahasiswa Fakultas Psikologi UIN SUSKA Riau. Jurnal Psikologi, Vol 1, No. 2, 69-77.

A.W. Munawwir, Kamus AlMunawwir, Pustaka Progressif

Azwar, S. (2007). Metode Penelitian.Yogyakarta : Pustaka Pelajar

Budiman, Wijaya. 2014. Purchase Intention of Counterfeit Products: The Role of Subjectivem Norm. International Journal of Marketing Studies. 4 (6); pp:95-102. 
Zahro, et al/Jurnal Ekonomi Syariah Teori dan Terapan Vol. 6 No. 6 Juni 2019: 1209-1227; ANALISIS THEORY OF PLANNED BEHAVIOUR DAN PENGETAHUAN TERHADAP NIAT BERINFAQ JAMAAH MAJELIS TAKLIM KECAMATAN SUKOMANUNGGAL SURABAYA

Dewan Redaksi Ensiklopedi. 1994. Ensiklopedi Islam. Jakarta: PT. Ichtiar Baru Van Hoeve. Cetakan Keempat. Jilid 3

Fishbein dan Ajzen, 1975. Belief, Attitude, Intentions and Behavior: an introduction to theory and research. California: AddisonWesley Publishing Company, Inc.

Ghozali, Imam. 2007. Aplikasi Analisis Multivariate dengan program SPSS. Cetakan keempat.Semarang :Badan Penerbit Universitas Diponegoro

Hafidhuddin, Didin. 2002. Zakat dalam Perekonomian Modern. Jakarta: Gema Insani.

Hakim, Lukman. Prinsip-Prinsip Ekonomi Islam. Surakarta: Erlangga. 2012.

Jogiyanto, 2007. Sistem Informasi Keperilakuan. Edisi Revisi. Yogyakarta: Andi Offset

Machrus, Hawa'im dan Urip Purwono Pengkuran Perilaku berdasarkan Theory of Planned Behavior, INSAN Vol. 12 No. 01, April 2010

Mowen, John, C dan Michael Minor. 2002. Perilaku Konsumen. Jilid Kedua. Jakarta: Erlangga.

Munsin MK, Manajemen Majelis Taklim, Jakarta: Pustaka Intermasa, 2009

Notoatmodjo, S. 2003. Pendidikan dan Perilaku Kesehatan. Jakarta: Rineka Cipta

Rakhmat, J. (2005). Metode Penelitian Komunikasi. Bandung: PT Remaja Rosdakarya.
Schiffman, L.G. dan Kanuk, L.L. 2004. Perilaku Konsumen. Edisi ketujuh. Prentice Hall International.

Sekaran, Uma. 2006. Metodologi Penelitian Untuk Bisnis. Jilid 1. Edisi 4. Salemba Empat, Jakarta.

Sugiyono.2013. Metodee Penelitian Kuantitatif Kualitatif dan R\&D. Cetakan ke-22. Bandung: Alfabet. 